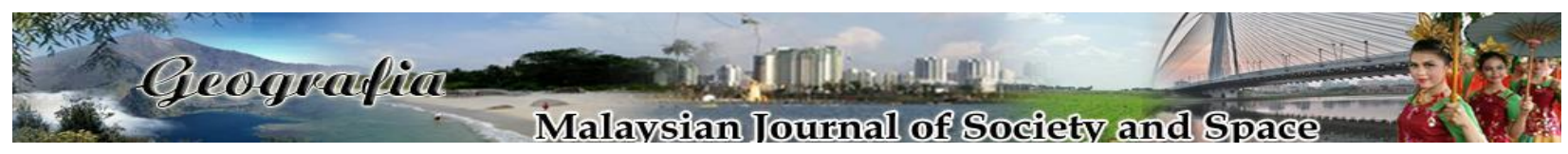

\title{
Impak perusahaan sosial terhadap pembangunan komuniti rentan dan alam sekitar di Malaysia
}

\author{
Rusyda Ramly, Sarmila Md. Sum, Suraiya Ishak, Seng Boon Lim \\ Pusat Kajian Pembangunan, Sosial dan Persekitaran, Fakulti Sains Sosial dan Kemanusiaan, \\ Universiti Kebangsaan Malaysia \\ Correspondence: Seng Boon Lim (lims@ukm.edu.my)
}

Received: 12 October 2020; Accepted: 10 April 2021; Published: 29 May 2021

\begin{abstract}
Abstrak
Perusahaan sosial adalah merupakan satu model menyelesaikan pelbagai masalah menerusi elemen perusahaannya yang banyak diaplikasikan oleh seluruh dunia bagi membangunkan kesejahteraan komuniti sejagat. Keadaan ini juga menjadikan perusahaan sosial ini dapat menyumbang kepada sesebuah komuniti menerusi matlamat yang dibangunkan dalam perusahaan sosial tersebut. Namun begitu, sejauh manakah perusahaan sosial dapat menyumbang kepada sesebuah komuniti seperti membendung ketidaksamaan sosial adalah perlu dikaji. Oleh itu, objektif artikel ini adalah untuk mengenal pasti impak perusahaan sosial terhadap komuniti di Malaysia. Kajian ini merupakan suatu kajian awalan dan menggunakan pendekatan kualitatif menerusi kaedah temu bual bersemuka. Temu bual bersemuka dijalankan bersama tiga informan pemilik perusahaan sosial. Naratif temu bual dianalisis menggunakan kaedah tematik dengan bantuan perisian Atlas.ti. Hasil kajian telah mengenal pasti 31 tema asas, lapan tema utama, dan tiga kategori. Tiga kategori yang dikenal pasti dalam mencapai objektif termasuk a) menerusi membantu golongan rentan, b) meningkatkan ekonomi menerusi peningkatan pendapatan, serta c) membantu dalam memelihara dan memulihara alam sekitar. Namun, hasil dapatan menerusi kategori tersebut tidak mencakupi keseluruhan aspek terutama sekali bagi impak dalam aspek kebajikan yang boleh lagi dipertingkatkan. Hasil analisis tersebut turut mendapati matlamat perusahaan sosial kurang menekankan isu bagi membendung ketidaksamaan sosial. Sesebuah perusahaan sosial tidak mempunyai masalah sekiranya mereka hanya memberi impak tertentu untuk jangka masa pendek. Walau bagaimanapun, bagi jangka masa panjang, matlamat tanggungjawab sosial pengusaha terhadap kebajikan masyarakat dan ketidaksamaan sosial adalah disyorkan dikembangkan melalui instrumen inovasi sosial.
\end{abstract}

Kata kunci: Inovasi sosial, ketidaksamaan sosial, komuniti rentan, pembangunan komuniti, pembasmian kemiskinan, tanggungjawab sosial 


\title{
Impact of social enterprise to the vulnerable community development and environment in Malaysia
}

\begin{abstract}
Social enterprise is a model of solving various problems through its enterprise elements that are widely applied by the whole world to develop the well-being of the global community. This situation also makes this social enterprise can contribute to a community through the goals developed in the social enterprise. However, how well does this enterprise contribute to the development of a community such as curbing social injustice are subjected to explore. Therefore, the objective of this article is to identify the impact of the social enterprises to the community in Malaysia. This study is a preliminary study and uses a qualitative approach through face-to-face interview methods. Face-to-face interviews were conducted with three informants of social enterprise owners. Interview narratives were analyzed using thematic methods with the help of Atlas.ti software. The results of the study have identified 31 basic themes, eight main themes, and three emerging categories. The three categories that have been identified in achieving the objectives include a) through helping the vulnerable, b) improving the economy through increasing income, as well as c) assisting in preserving and conserving the environment. However, the findings through these categories do not cover the whole aspect, especially for contributions in the welfare aspect that can be further enhanced. The results of the analysis also found that the goal of social enterprise is less emphasis on issues to curb social inequality. A social enterprise has no problem if they only make certain contributions for a short period of time. However, in the long run, the goals of entrepreneurs' social responsibility towards social welfare and social inequality are recommended to be developed through social innovation instruments.
\end{abstract}

Keywords: Social innovation, social injustice, vulnerable community, community development, poverty elimination, social responsibility,

\section{Pengenalan}

Perusahaan sosial dilihat sebagai alat penting bagi menyelesaikan masalah sosial dalam kalangan rakyat sesebuah negara (Lateh, Hussain, \& Abdullah, 2018). Menurut Sheheryar, Kazmi dan Hashim (2016), perusahaan sosial mempunyai pendekatan yang menjanjikan untuk menghapuskan kemiskinan dan membantu meningkatkan ekonomi. Masalah kemiskinan secara globalnya sering menjadi isu sosial yang diketengahkan pada hari ini (Fotheringham \& Saunders, 2014). Contohnya, dalam Agenda Pembangunan Lestari 2030, kadar kemiskinan yang tinggi serta pendapatan per kapita rendah terus menjadi matlamat penting pembangunan mapan di negaranegara membangun (Development Strategy and Policy Analysis Unit, 2017).

Kini masalah sosial jika dilihat di negara maju tidak terarah kepada masalah kemiskinan sahaja tetapi ia turut melibatkan isu sosial lain seperti kekangan dalam mendapatkan peluang pekerjaan, kesihatan, pendidikan serta persekitaran yang semakin merumitkan lagi keadaan sosial masyarakat (Becchetti \& Borzaga, 2010). Secara tidak langsung keadaan ini telah menyebabkan ketidaksamaan sosial yang dihadapi oleh golongan rentan (vulnerable group) kerana identiti seperti isu jantina, kurang upaya (OKU), etnik, bangsa dan kasta (Rohwerder, 2016). Dalam 
menangani ketidaksamaan sosial yang berlaku, kajian ini cuba melihat apakah impak perusahaan sosial melalui matlamat yang terbentuk dalam membantu membangunkan komuniti. Adakah ketidaksamaan sosial dapat dibendung dan dicapai melalui matlamat sumbangan perusahaan sosial, dan sejauh mana perusahaan sosial ini dapat memberi manfaat terhadap pembangunan komuniti? Sehubungan itu, objektif kajian ini bertujuan untuk meneliti impak yang dapat diberikan oleh perusahaan sosial terhadap pembangunan komuniti menerusi kajian kes yang dilakukan terhadap tiga buah perusahaan sosial yang terdapat di Malaysia. Kajian ini adalah penting di Malaysia kerana masih kurang bukti yang membincangkan impak perusahaan sosial, khasnya dalam aspek pembangunan komuniti

\section{Sorotan literatur}

\section{Konsep perusahaan sosial}

Perusahaan sosial bukan satu fenomena baru yang muncul di seluruh dunia menerusi pendekatan perusahaan kepada masalah sosial yang berlaku (International Labour Organization, 2011; Mthembu \& Barnard, 2019). Keadaan ini dapat dibuktikan melalui kemunculan konsep perusahaan sosial pada tahun 1980 yang disebabkan oleh perkhidmatan kebajikan yang sedia ada gagal untuk memenuhi keperluan dan gagal untuk menyokong pembangunan ekonomi masyarakat (Becchetti \& Borzaga, 2010). Kini, konsep perusahaan sosial sering dibincangkan oleh kebanyakan negara dan ia dikaitkan dengan sektor ketiga serta sektor bukan keuntungan (NPO) (Babos, Clarence, \& Noya, 2006).

Konsep perusahaan sosial adalah satu model ekonomi yang mempunyai dua fokus utama terhadap pulangan ekonomi dan sosial (Baldwin, 2009; Maguirre, Ruelas, \& Torre, 2016). Konsep ini juga adalah hasil inisiatif rakyat yang melibatkan mereka menjadi sebahagian daripada komuniti atau kumpulan yang berkongsi keperluan atau tujuan yang sama (OECD, 2007). Pada tahun 2015, perusahaan sosial telah diangkat dalam Agenda Pembangunan Mampan 2030 dan 17 Matlamat Pembangunan Mampan (Sustainable Development Goals) bertujuan bagi mencapai tujuannya menerusi sumbangannya (Littlewood \& Holt, 2018). Pada peringkat pelaksanaan perusahaan sosial mempunyai dua ciri utama iaitu, inovasi sosial dan berskala (Maguirre et al., 2016) Inovasi sosial bermaksud perubahan positif pada peringkat konseptual, proses, produk atau organisasi dengan penggunaan sumber yang menyumbang kepada pencapaian matlamat sosial (Mair \& Marti, 2006). Manakala bagi skala keusahawanan sosial pula merujuk kepada keupayaan untuk berjaya membawa model perusahaan yang sama ke tempat lain untuk terus menjana faedah sosial (Martin \& Osberg 2007). Perusahaan sosial juga turut menggabungkan pandangan, rasa belas kasihan dan imaginasi bagi menyelesaikan masalah sosial serta alam sekitar (British Council, 2017).

Pembangunan model perusahaan sosial ini juga dilihat merupakan aspek utama dalam pembangunan sosial dan ekonomi di Eropah (Vveinhardt, J. \& Kuklyte, 2016). Di Eropah, perusahaan sosial ini dicorakkan menerusi pengaruh pembangunan insentif oleh sektor ketiga yang memerlukan kemahiran profesional dan cara pengurusan yang efektif untuk memandu struktur tidak berkeuntungan ini untuk mengguna pakai tingkah laku perusahaan (Bahena-Álvarez, Cordón-Pozo, \& Delgado-Cruz, 2019). Namun, konsep perusahaan sosial ini tidak bertujuan untuk menggantikan konsep sektor bukan keuntungan atau ekonomi sosial tetapi ia secara langsung terlibat dalam pengeluaran atau penjualan barangan dan perkhidmatan (OECD, 2007). Di 
Sepanyol, perusahaan sosial sering dikaitkan dengan inisiatif koperasi sosial yang dapat memberi penyelesaian kepada pembangunan sosial komuniti terutamanya kepada kesihatan, pendidikan, kebudayaan, integrasi kerja atau pengecualian sosial (social exclusion) (Pfeilstetter \& GómezCarrasco, 2017).

Kini perusahaan sosial merupakan alat yang digunakan secara meluas serta berpotensi untuk menyumbang kepada pertumbuhan ekonomi tempatan melalui penghasilan produk dan penawaran perkhidmatan yang diberikan kepada golongan terpinggir, khususnya bagi masyarakat di kawasan bandar atau luar bandar (Babos et al., 2006). Perusahaan sosial juga berusaha untuk membangunkan masyarakat yang saksama dan adil, iaiatu keperluan semua masyarakat dapat direalisasikan sepenuhnya (British Council, 2017). Menurut laporan kajian yang dilakukan oleh Community Wealth Ventures (2009), bilangan perusahaan sosial telah berkembang sejak tahun 1970-an dan pertumbuhannya menjadi semakin pesat sekitar tahun 1990-an dan awal tahun 2000 menerusi pelbagai impaknya terhadap masyarakat. Antara impaknya adalah menerusi ekonomi dan sosial seperti memberi peluang pekerjaan yang lebih baik kepada golongan rentan. Contohnya, di Romania, perusahaan sosial membantu mereka dengan memberi peluang kepada golongan rentan menerusi industri pelancongan (Iorgulescu \& Răvar, 2015).

\section{Matlamat perusahaan sosial}

Sebelum ini kerajaan menjadi harapan besar rakyat untuk menyelesaikan masalah sosial dan telah membawa kejayaan kepada peningkatan kebajikan sosial seperti akses kepada pendidikan serta penjagaan kesihatan. Namun begitu, terdapat juga batasan untuk memenuhi keseluruhan keperluan sosial yang diperlukan oleh rakyat (Mthembu \& Barnard, 2019). Oleh yang demikian, perusahaan sosial yang merangkumi pelbagai aspek aktiviti sosial menjadi harapan untuk membantu menyelesaikan masalah sosial komuniti.

Perusahaan sosial ini juga dapat memberi manfaat bagi golongan wanita kerana pada peringkat global kerana mereka terdedah dengan risiko seperti masalah kemiskinan, keganasan dan penderaan (Richardson \& Sappal, 2017). Oleh itu, menerusi perusahaan sosial dapat memberi kesan positif kepada mereka melalui kemahiran, peluang pekerjaan dan peningkatan ekonomi (Richardson \& Sappal, 2017).

Selain daripada itu, perusahaan sosial juga turut membantu golongan pelarian terutamanya dalam memberi peluang pekerjaan. Ini disebabkan golongan pelarian mempunyai cabaran dari segi kemahiran bahasa atau mempunyai kesulitan dalam kelayakan yang diperlukan oleh pihak majikan (Freudenberg \& Halberstadt, 2018). Perusahaan sosial berpotensi untuk melengkapi dan mempercepatkan keperluan pelarian yang belum atau tidak dapat dipenuhi oleh pihak yang berkaitan (Harima \& Freudenberg, 2019). Dalam erti kata lain, menerusi perusahaan sosial ini ia mewujudkan nilai sosial dan membantu penyesuaian pelarian dengan kehidupan masyarakat setempat dengan penyelesaian yang lebih lestari (Mollaogullari \& Temel, 2017). Keadaan ini adalah disebabkan oleh sesetengah daripada mereka mungkin mengalami trauma atau kekurangan kemahiran pekerjaan yang diperlukan di negara tuan rumah mereka (Freudenberg \& Halberstadt, 2018).

Pelbagai matlamat dapat diberi oleh perusahaan sosial ini supaya dapat memberi faedah kepada pembangunan komuniti sekiranya ia dijalankan dengan sempurna. Antara matlamat perusahaan sosial ini adalah menyumbang kepada nilai ekonomi menerusi penciptaan peluang pekerjaan sebagaimana kajian yang dilakukan oleh Baldwin (2009) di Ontario. Beliau menjelaskan bahawa perusahaan sosial ini mampu untuk memacu pertumbuhan yang penting dalam semua 
bentuk orgnisasinya menerusi pertumbuhan ekonomi dan sosial.Selain itu menerusi perusahaan sosial ini juga dapat membantu mereka yang mempunyai kadar kelayakan yang rendah agar tidak terkecuali daripada pasaran buruh (Bahena-Álvarez et al., 2019). Jika dilihat di beberapa negara di Eropah mereka memperkenalkan beberapa skim yang berkaitan perusahaan sosial yang dapat menyumbang kepada inisiatif pertumbuhan pekerjaan seperti skim awam yang menyasarkan integrasi kerja melalui perusahaan sosial (Defourny \& Nyssens, 2008). Menurut Defourny dan Nyssens (2008), skim ini berfokus kepada integrasi kerja perusahaan, latihan perusahaan di tempat kerja dan bengkel sosial seperti yang dilakukan di Belgium dan Sepanyol.

Selain itu, perusahaan sosial dibangunkan sebagai penyelesaian bagi perkhidmatan awam yang lemah (Humphries, 2011). Perkhidmatan awan yang lemah dapat dibantu apabila perusahaan sosial menyalurkan bantuan kebajikan terhadap penjagaan kesihatan penduduk terutamanya di kalangan penduduk luar bandar (Madan, 2014). Kepentingan penjagaan kesihatan ini adalah amat penting bagi memberi kesejahteraan hidup kepada rakyat (Stumbitz et al., 2018). Sebagaimana yang dilakukan oleh perusahaan sosial di India dan Kenya apabila mereka menggunakan perusahaan sosial ini bagi memacu peningkatan dalam perkhidmatan penjagaan kesihatan melalui capaian piawaian yang berkualiti tinggi bagi melayani pelanggan berpendapatan rendah, harga yang berpatutan serta meningkatkan harapan masyarakat untuk menjalani kehidupan yang sihat (Humphries, 2011).

Matlamat perusahaan sosial juga turut bertumpu kepada penyelesaian terhadap isu alam sekitar (Bansal, Garg, \& Sharma, 2019). Jika dilihat di Scotland mereka menggunakan perusahaan sosial bagi menguruskan pengurusan sisa buangan mereka (Brook Lyndhurst, 2007). Selain daripada itu, perusahaan sosial dibangunkan untuk mencapai matlamat sisa sifar melalui pendekatan kitar semula sebagai langkah pertama yang diambil oleh perusahaan sosial di samping memperbaiki dan kemudiannya menjual barangan yang dibaik pulih kepada komuniti setempat (Zaman, 2012). Perusahaan sosial juga turut mengambil pendekatan inovasi sosial dalam sektor alam sekitar menerusi pembabitan kumpulan sosial dan masyarakat setempat dalam mencipta, membangunkan serta menyebarkan idea di samping sebagai penyelesaian untuk menangani keperluan sosial (European Commission, 2014).

\section{Metodologi kajian}

Kajian ini merupakan kajian kualitatif awalan bagi penyelidikan matlamat perusahaan sosial. Terdapat tiga buah perusahaan sosial yang dijadikan kes bagi mendapatkan data mengenai impak perusahaan sosial terhadap pembangunan komuniti.

\section{Sifat kajian kes}

Informan kajian yang terpilih adalah pemilik perusahaan sosial di tiga buah tempat iaitu di Selayang (Perusahaan Sosial 1 atau SE1), Kuching (SE2) dan Klang (SE3), Malaysia. SE1 mempunyai objektif sosial untuk membantu golongan pelarian dan menyelamatkan alam sekitar melalui inovasi sosial menerusi pembuatan barangan daripada barangan terpakai. Manakala, SE2 dijalankan di Kuching, Sarawak yang mempunyai objektif sosial untuk membantu golongan petani. SE3 pula ditubuhkan bertujuan untuk membantu golongan ibu tunggal menerusi pembuatan produk daripada barangan terpakai. Syarikat perusahaan sosial yang dipilih sebagai kajian kes ini adalah merupakan perusahaan sosial yang dilaksanakan oleh usahawan sosial yang didaftarkan di 
bawah Malaysian Global Innovation \& Creativity Centre (MaGIC). MaGIC adalah merupakan sebuah agensi di bawah Kementerian Sains, Teknologi dan Inovasi (MOSTI) yang memudahkan, mengemudi dan membolehkan ekosistem dalam memperkukuhkan Malaysia sebagai sebuah negara inovasi yang baru ditubuhkan (Nasir \& Subari, 2017).

Perusahaan sosial yang dipilih dalam kajian ini menjalankan perusahaan dengan penawaran pengeluaran produk bagi mendukung misi sosial mereka. Keterangan teliti berkaitan dengan tempoh beroperasi, matlamat sosial, golongan sasaran, aktiviti, dan keterlibatan golongan sasaran diterangkan dalam Jadual 1.

Jadual 1. Perbandingan kajian kes perusahaan sosial

\begin{tabular}{|c|c|c|c|}
\hline \multirow{2}{*}{ Sifat } & \multicolumn{3}{|c|}{ Perusahaan Sosial } \\
\hline & SE1 & SE2 & SE3 \\
\hline $\begin{array}{l}\text { Jenis Perusahaan } \\
\text { Sosial }\end{array}$ & Perkongsian & Persendirian & Persendirian \\
\hline Lokasi & Selayang, Selangor & Kuching, Sarawak & Klang, Selangor \\
\hline Tempoh & 3 tahun & 2 tahun & 4 tahun \\
\hline Beroperasi & & & \\
\hline Matlamat Sosial & $\begin{array}{l}\text { Menyelamatkan alam sekitar \& } \\
\text { membantu golongan ibu tunggal } \\
\text { pelarian }\end{array}$ & $\begin{array}{l}\text { Membantu } \\
\text { memperkasakan } \\
\text { golongan petani }\end{array}$ & $\begin{array}{l}\text { Menyelamatkan alam sekitar } \\
\& \text { membantu golongan ibu } \\
\text { tunggal }\end{array}$ \\
\hline $\begin{array}{l}\text { Golongan } \\
\text { Sasaran }\end{array}$ & Golongan ibu tunggal & Golongan Petani & Golongan Ibu Tunggal \\
\hline Aktiviti/ Program & $\begin{array}{l}\text { Menghasilkan produk } \\
\text { menggunakan pakaian terpakai }\end{array}$ & $\begin{array}{l}\text { Menghasilkan produk } \\
\text { kulit (skin care) }\end{array}$ & $\begin{array}{l}\text { Menghasilkan produk } \\
\text { menggunakan pakaian } \\
\text { terpakai }\end{array}$ \\
\hline $\begin{array}{l}\text { Keterlibatan } \\
\text { golongan sasaran }\end{array}$ & $\begin{array}{l}\text { Terlibat dalam penghasilan } \\
\text { produk }\end{array}$ & $\begin{array}{l}\text { Terlibat dalam memberi } \\
\text { hasil pertanian }\end{array}$ & $\begin{array}{l}\text { Terlibat dalam penghasilan } \\
\text { produk }\end{array}$ \\
\hline
\end{tabular}

Nota: SE bermaksud perusahaan sosial.

Mengikut ketepuan data, pengkaji mendapati tiga kes informan yang ditemu bual adalah mencukupi kerana tema-tema yang dibangkitkan didapati berulang mulai kes ketiga. Maka, perbincangan antara para pengkaji telah memutuskan ketepuan data telah tercapai (Saunders et al., 2018) dan tiga kes yang ditemu bual adalah mencukupi untuk kajian awalan penyelidikan ini.

\section{Kaedah temu bual dan analisis tematik}

Kajian ini menggunakan pendekatan kualitatif menerusi kaedah temu bual bersemuka. Data temu bual dianalisis menggunakan kaedah analisis tematik yang bertujuan untuk mengenal pasti corak atau tema dalam data kualitatif (Fereday \& Muir-Cochrane, 2006). Menurut Sarmila (2012), penggabungan kod yang digabungkan dirujuk sebagai tema asas (TA) dan seterusnya maknamakna yang telah di formulasi pula akan dikategorikan serta digabungkan kepada kelompok yang membentuk apa yang dirujuk sebagai tema utama (TU) bagi sesuatu kajian. Akhirnya, antara tematema utama, suatu kategori (K) akan diterbitkan untuk menyimpulkan tema yang mempunyai ciriciri sepunya (Rajah 1). 


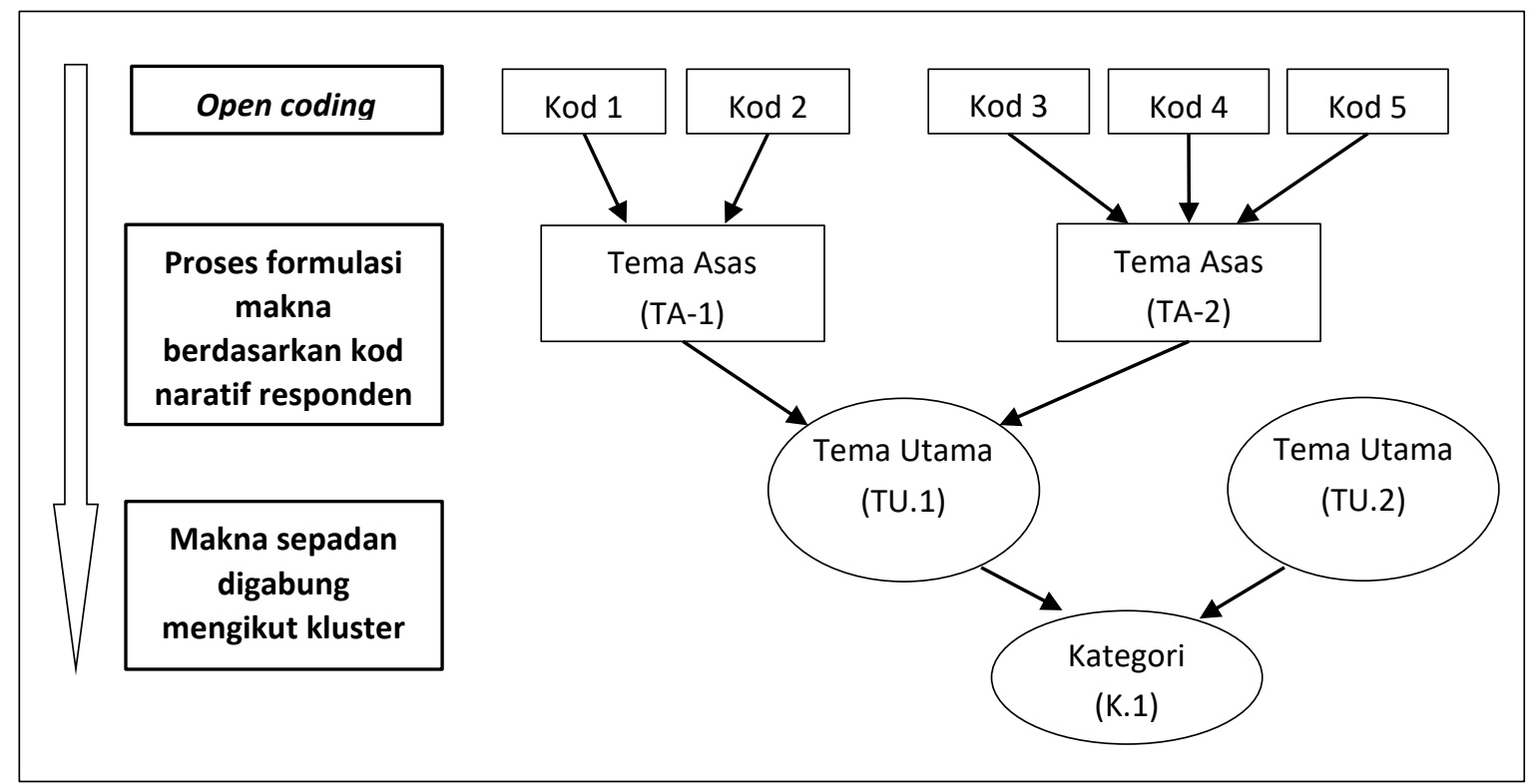

Sumber: Diubahsuai daripada Sarmila (2012)

Rajah 1. Proses membangunkan tema kajian.

\section{Hasil kajian}

Berdasarkan hasil analisis, kajian ini telah mengenal pasti terdapat 31 tema asas (TA) dan lapan tema utama (TU), dan tiga kategori (K) berdasarkan naratif responden yang muncul daripada analisis data kajian berkaitan impak perusahaan sosial terhadap pembangunan komuniti di Malaysia. Pembentukan tema-tema berkaitan diperjelaskan dalam Jadual 2. Huraian seterusnya adalah mengikut urutan kategori, iaitu "K1: Jenis komuniti rentan (vulnerable community) yang dibantu", "K2: Membasmi kemiskinan", dan "K3: Memelihara dan memulihara alam sekitar".

Jadual 2. Pembentukan tema asas, tema utama, dan kategori kajian

\begin{tabular}{lll}
\hline \multicolumn{1}{c}{ Tema Asas (TA) [kod] } & Tema Utama (TU) & \multicolumn{1}{c}{ Kategori (K) } \\
\hline $\begin{array}{l}\text { Membantu pelarian etnik Rohingya [1] } \\
\text { Memberi bantuan kepada golongan wanita [2] }\end{array}$ & $\begin{array}{l}\text { TU.1. Golongan } \\
\text { pelarian }\end{array}$ & $\begin{array}{l}\text { K.1. Jenis komuniti } \\
\text { rentan (vulnerable } \\
\text { community) yang } \\
\text { mendibantu }\end{array}$ \\
$\begin{array}{l}\text { Membantu pekerjaan [1] } \\
\text { Membantu membeli hasil pertanian golongan petani [3] }\end{array}$ & $\begin{array}{l}\text { TU.2. Golongan } \\
\text { petani }\end{array}$ & \\
$\begin{array}{l}\text { Membantu menjana pendapatan [8] } \\
\text { Membantu menyediakan peralatan pertanian [1] }\end{array}$ & \\
$\begin{array}{l}\text { Membantu petani mendapatkan sijil pertanian [1] } \\
\text { Memperkasakan golongan petani [1] }\end{array}$ & \\
$\begin{array}{l}\text { Membantu ibu tunggal [2] } \\
\text { Membantu ibu tunggal dengan kemahiran [3] } \\
\text { Membantu menambahkan pendapatan [1] }\end{array}$ & \\
$\begin{array}{l}\text { Membantu menjana pendapatan [8] } \\
\text { Memberi latihan kepada ibu tunggal [2] }\end{array}$ & TU.3. Golongan ibu \\
tunggal & \\
& & \\
\end{tabular}




\begin{tabular}{|c|c|c|}
\hline $\begin{array}{c}\text { Tema Asas (TA) [kod] } \\
\end{array}$ & Tema Utama (TU) & Kategori (K) \\
\hline \multicolumn{3}{|l|}{ Memberi peluang pekerjaan kepada golongan ibu tunggal [1] } \\
\hline \multicolumn{3}{|l|}{ Memberi sokongan kepada ibu tunggal [2] } \\
\hline Memberi peluang pekerjaan kepada golongan ibu tunggal [5] & \multirow{3}{*}{$\begin{array}{l}\text { TU.4. Memberi } \\
\text { peluang pekerjaan }\end{array}$} & \multirow{13}{*}{$\begin{array}{l}\text { K.2. Membasmi } \\
\text { kemiskinan }\end{array}$} \\
\hline $\begin{array}{l}\text { Memberi peluang pekerjaan kepada golongan yang sukar } \\
\text { mendapat kerja [1] }\end{array}$ & & \\
\hline Mengambil pekerja separuh masa [1] & & \\
\hline Memberi latihan kepada ibu tunggal [2] & \multirow{3}{*}{$\begin{array}{l}\text { TU.5. Memberi } \\
\text { latihan kemahiran }\end{array}$} & \\
\hline Membuat produk daripada barang terpakai [2] & & \\
\hline Membantu ibu tunggal dengan kemahiran [3] & & \\
\hline Membantu menampung perbelanjaan anak-anak [1] & \multirow{4}{*}{$\begin{array}{l}\text { TU.6. Menjana } \\
\text { pendapatan }\end{array}$} & \\
\hline Membantu menjana pendapatan [8] & & \\
\hline Membantu menjana pendapatan melalui program latihan [1] & & \\
\hline Memberi bantuan kepada golongan wanita pelarian [1] & & \\
\hline Membantu golongan berpendapatan rendah [2] & \multirow{3}{*}{$\begin{array}{l}\text { TU.7. Menambah } \\
\text { pendapatan }\end{array}$} & \\
\hline Membantu membeli hasil pertanian golongan petani [3] & & \\
\hline Membantu menambahkan pendapatan [1] & & \\
\hline Melalui program kitar semula barangan [2] & TU.8. & K.3. Memelihara dan \\
\hline Membuat produk daripada barangan terpakai [2] & $\begin{array}{l}\text { Menyelamatkan } \\
\text { alam sekitar }\end{array}$ & $\begin{array}{l}\text { memulihara alam } \\
\text { sekitar }\end{array}$ \\
\hline
\end{tabular}

\section{Sasaran pembangunan golongan rentan}

Hasil daripada temu bual yang dijalankan pengkaji membangunkan kategori pertama, 'K.1. Jenis komuniti rentan (vulnerable community) yang dibantu'. Dalam interpretasi verbatim, tiga golongan sasaran bantuan telah dibangkitkan oleh informan, iaitu golongan pelarian Rohingya wanita, petani, dan ibu tunggal.

\section{a. Golongan pelarian Rohinya}

Pengasas perusahaan sosial SE1 membantu golongan Rohingya menerusi kemahiran yang diberikan kepada golongan wanita pelarian. Pelarian wanita Rohinya merupakan golongan yang tidak pandai berbahasa Melayu, tidak memahami budaya tempatan, menjaga anak yang ramai serta tidak mempunyai kemahiran yang dapat menjana pendapatan. Keadaan mereka adalah sepadan dengan hujah Kooy (2016), bahawa golongan pelarian menghadapi halangan untuk menjadi sebahagian tenaga kerja kerana masalah yang berkaitan bahasa, budaya, jantina dan keluarga serta sikap dan amalan majikan.

\section{b. Golongan petani}

Melalui hasil data juga mendapati perusahaan sosial turut membantu golongan petani. Pengasas perusahaan sosial SE2 menerangkan mereka cuba membantu petani mencari pasaran untuk memasarkan hasil pertanian dan membantu petani mendapatkan sijil pertanian. Hala perusahaan sosial dalam membantu golongan petani dalam kes kajian adalah mirip kepada pendapat Zhang (2016) bahawa perusahaan sosial mampu memberi peluang kepada para petani meningkatkan hasil pendapatan mereka melalui membantu mereka menjual hasil mereka terus kepada pengguna. 
Keadaan ini menjadikan perusahaan sosial sangat penting dalam pembangunan ekonomi terutama sekali dalam sektor pertanian (Mohapatra, Khadanga, \& Majhi, 2018).

c. Golongan ibu tunggal

Selain daripada itu juga, hasil analisis data pada pengasas perusahaan sosial SE3 mendapati perusahaan sosial turut membatu golongan wanita melalui penawaran peluang pekerjaan kepada mereka terutamanya golongan ibu tunggal. Keadaan ini juga turut disokong oleh Medel-anonuevo (1995) yang menyatakan bahawa golongan wanita perlu dibantu melalui penyediaan projek penjanaan pendapatan yang berorientasikan pasaran dan bukan projek berorientasikan kebajikan. Kini kebanyakan negara juga turut memberi penekanan terhadap kemajuan ekonomi wanita dan turut melaksanakan program pembangunan wanita (Parvin, Ahsan, \& Chowdhury, 2004). Keadaan yang demikian memperlihatkan impak perusahaan sosial ini terhadap pemerkasaan wanita menjadi sangat penting dan boleh membawa impak yang besar kepada modal insan sesebuah negara.

\section{Pulangan sosial dalam membasmi kemiskinan}

Hasil daripada analisis mendapati perusahaan sosial mampu menjana pulangan sosial dalam pembangunan komuniti. Secara tidak langsung dapat membantu membasmi masalah kemiskinan komuniti yang memerlukan bantuan. Maka, di bawah Kategori kedua, 'K.2. Membasmi kemiskinan', empat tema utama yang muncul adalah seperti, 'TU.4. Memberi peluang pekerjaan, TU.5. Memberi latihan kemahiran, TU.6. Menjana pendapatan, dan TU.7. Menambah pendapatan'.

\section{a. Memberi peluang pekerjaan}

Dalam hal ini, SE1 menyatakan perusahaan sosial mereka turut menyumbang kepada pertumbuhan peluang pekerjaan. Dalam operasi mereka, sasaran golongan wanita, iaitu ibu tunggal Rohingya diupah sebagai pekerja sepenuh masa seperti yang diperkatakan oleh pengusaha SE1,

\section{"Kami tubuhkan perusahaan ini untuk membantu mereka dalam memberi mereka peluang pekerjaan sebab mereka ni antara pelarian yang sukar untuk mendapat pekerjaan".}

Keadaan ini dapat membantu golongan tersebut untuk mendapatkan peluang pekerjaan. Hal ini turut disokong oleh Sheheryar et al. (2016) dan Eurofound (2019) yang menyatakan bahawa perusahaan sosial dapat mewujudkan peluang pekerjaan bagi menyelesaikan masalah sosial, menambahkan pendapatan, menyediakan perkhidmatan dan produk yang inovatif bagi menggalakkan ekonomi yang mampan serta ia dianggap sebagai agen perubahan untuk memperbaiki kehidupan komuniti.

\section{b. Memberi latihan kemahiran}

Menerusi elemen memberi latihan kemahiran, dapatan menunjukkan terdapat perusahaan yang membantu dalam memberi latihan kemahiran sebagaimana yang dilakukan oleh SE3 iaitu, 
"Daripada ibu-ibu tunggal ni yang kebanyakannya ni semua tiada kebolehan menjahit, kita latih dia”.

Pemberian latihan ini adalah merupakan proses penyediaan pekerja dengan kemahiran tertentu atau membantu mereka memperbaiki kekurangan dalam prestasi yang secara tidak langsung dapat membantu komuniti yang dibantu untuk menjalankan tugas dengan cekap (Makararavy \& Anurit, 2009). Keadaan yang demikian adalah bertepatan dengan hasil analisis kajian ini yang mendapati komuniti yang dibantu telah diberi latihan untuk meningkatkan taraf hidup mereka.

\section{c. Menjana pendapatan}

Perusahaan sosial juga memperlihatkan ia mampu untuk meningkatkan pendapatan komuniti. Menerusi tema utama ini, SE3 membantu golongan ibu tunggal yang mempunyai masalah pendapatan menerusi memberi mereka kemahiran yang membolehkan mereka untuk menghasilkan produk sebagaimana yang diperkatakan oleh SE3,

"Sebab jika mereka belajar untuk buat beg ni dan mengambil inisiatif untuk boleh buat sendiri dan jual pada kawan-kawan yang secara tidak langsung dapat menambahkan pendapatan mereka".

Menurut Sheheryar et al. (2016), keadaan ini disebabkan oleh perusahaan sosial ini yang berorientasikan pasaran bagi mewujudkan perubahan landskap untuk membantu meningkatkan taraf kehidupan individu yang berpendapatan rendah.

Selain daripada itu, perusahaan sosial juga dapat membantu meningkatkan hasil pendapatan komuniti. Kajian Sheheryar et al. (2016) menjelaskan, perusahaan sosial dapat membawa perubahan terhadap meringankan masalah kewangan. Keadaan ini bertepatan dengan hasil analisis dapatan yang mendapati perusahaan sosial dapat membantu golongan yang berpendapatan rendah meningkatkan ekonomi mereka di samping memperbaiki kehidupan mereka.

\section{d. Menambah pendapatan}

Menerusi hasil dapatan analisis juga, didapati perusahaan sosial dapat membantu dalam menambahkan pendapatan komuniti. Keadaan ini dapat dibuktikan melalui SE2 yang memberi peluang kepada para petani di kawasan pedalaman yang hanya menjana pendapatan mereka daripada hasil pertanian sahaja dan tidak mempunyai pasaran yang luas. Melalui bantuan yang diberikan oleh SE2 mereka dapat menambah pendapatan mereka melalui penjualan hasil pertanian mereka kepada SE2 seperti yang diperkatakan oleh SE2,

"Ya, sebab kami membantu memperkasakan komuniti petani ni dengan membeli hasil tanaman mereka”.

Keadaan ini juga dilihat sama menerusi kajian oleh Sheheryar et al. (2016) yang mana perusahaan sosial dapat meringankan masalah kewangan sebagaimana hasil analisis dapatan yang 
mendapati perusahaan sosial dapat membantu golongan yang berpendapatan rendah menambahkan pendapatan mereka.

\section{Pulangan alam sekitar: Memelihara dan memulihara alam sekitar}

Hasil daripada analisis impak perusahaan sosial terhadap pembangunan komuniti juga turut mendapati terdapat sumbangan perusahaan ini yang bertujuan menyelamatkan alam sekitar. Dapatan kajian mendapati perusahaan sosial di Malaysia mengambil pendekatan dengan melakukan inovasi terhadap barangan terpakai untuk dipasarkan. Keadaan ini dapat dilihat menerusi kajian oleh Zaman (2012) di Dhaka, mereka menggunakan perusahaan sosial untuk mempromosikan aktiviti kitar semula bersama-sama komuniti menerusi teknologi kompos.

Selain daripada itu, mereka turut menggunakan barangan yang mesra alam sebagaimana yang dijelaskan oleh Bansal et al. (2019). Dapatan ini jelas menunjukkan impak perusahaan sosial ini tidak terarah kepada satu misi sosial sahaja dalam sesebuah perusahaan tetapi ia boleh merangkumi pelbagai isu.

\section{Perbincangan}

Daripada hasil kajian, pengkaji telah merumuskan suatu kerangka hubungan impak perusahaan sosial dalam pembangunan komuniti (Rajah 2).

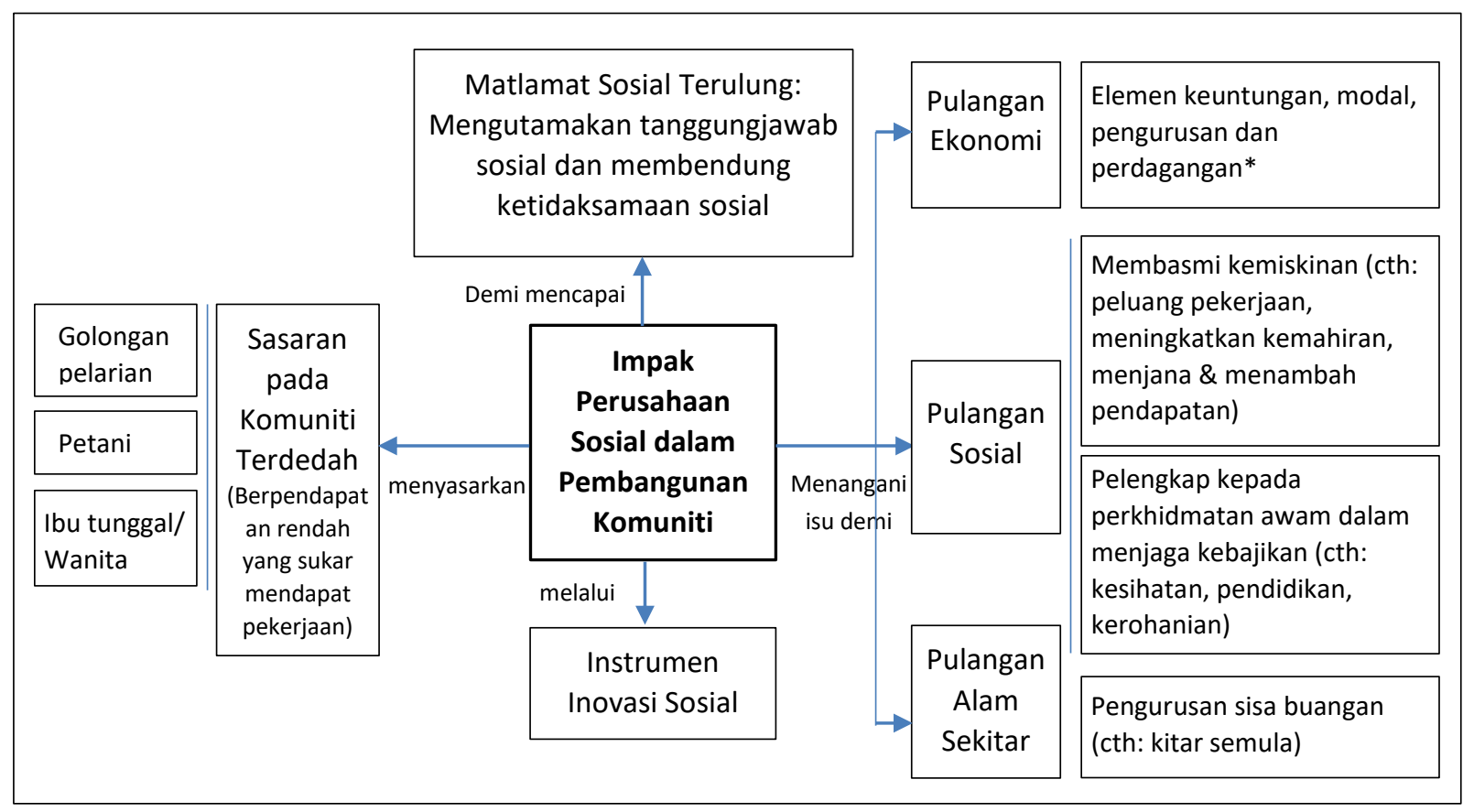

Nota: * Tidak diliputi dalam skop kajian

Rajah 2. Kerangka hubungan impak perusahaan sosial dalam pembangunan komuniti.

Daripada Rajah 2, didapati impak perusahaan sosial melalui elemen perusahaan dalam membangunkan komuniti rentan menyasarkan golongan berpendapatan rendah atau yang sukar 
mendapat pekerjaan termasuk golongan pelarian, petani, dan ibu tunggal. Impak tersebut adalah demi tujuan tiga pulangan yang utama, iaitu pulangan ekonomi, pulangan sosial, dan pulangan alam sekitar. Pulangan ekonomi termasuk elemen keuntungan, modal, pengurusan dan perdagangan adalah tidak diliputi dalam skop kajian ini. Pulangan sosial pula adalah penting dalam membasmi kemiskinan seperti membekalkan peluang pekerjaan, meningkatkan kemahiran, menjana dan menambah pendapatan golongan sasaran. Pulangan alam sekitar pula merangkumi bertanggungjawab dalam menyelamatkan alam seperti melalui pengurusan sisa buangan dan kitar semula. Secara umum, perusahaan sosial perlu mempunyai matlamat tertentu demi mencapai matlamat terulung, iaitu mengutamakan tanggungjawab sosial serta membendung ketidaksamaan sosial melalui instrumen inovasi sosial.

Hasil analisis, tiga kategori yang ditemui adalah merupakan perkara yang diambil berat oleh informan kajian. Pertama, mereka mengambil berat terhadap matlamat pertubuhan organisasi perusahaan sosial mereka sama ada dapat mencapai sasaran golongan komuniti rentan yang sangat memerlukan bantuan. Melalui matlamat perusahaan dan sosial yang sentiasa perlu diseimbangkan, sering kali mereka menghadapi cabaran pada pihak sasaran yang hendak dibantu. Cabarannya seperti, ada komuniti yang tidak cukup yakin, ada yang tidak tahu cara, dan ada yang tidak pandai berkomunikasi. Maka, informan perusahaan sosial sentiasa berusaha mengaplikasikan instrumen inovasi sosial untuk menangani cabaran tersebut. Contohnya inovasi pengurusan yang melalui peringkat kitaran inovasi bagi melakukan penyesuaian terhadap pengurusan mereka (Downey, 2007).

Kedua, kedua-dua pihak informan perusahaan sosial dan golongan yang dibantu adalah mengambil berat terhadap kenaifan dan kemiskinan kehidupan harian yang mencabar keluarga dan anak-anak mereka. Kemiskinan berlaku dalam pelbagai dimensi, seperti kemiskinan kebendaan termasuk kekurangan sumber makanan, tempat perlindungan, kemiskinan pemikiran dan tingkah laku termasuk kekurangan peluang berpendidikan asas dan tinggi, kekurangan peluang bergaul dengan masyarakat umum, kemiskinan kerohanian termasuk kekurangan tempat beribadat, dan peluang beribadat (OECD, 2015). Kes kajian mendapati kemiskinan jenis kebendaan yang sangat utama diberikan perhatian. Kemiskinan-kemiskinan yang dinyatakan di atas adalah antara sebabnya golongan rentan yang lambat laun terperangkap dalam fenomena 'ketidaksamaan sosial' dan berisiko dipinggirkan oleh masyarakat umum.

Ketidaksamaan sosial, khasnya yang dihadapi oleh komuniti rentan (atau komuniti yang terdedah/terpinggir/tertindas) di dalam kes kajian negeri Selangor dan Sarawak, adalah juga wujud di tempat-tempat lain di Malaysia. Dalam hal membendung kemiskinan, penemuan kajian menunjukkan kes kajian perusahaan sosial juga bermatlamat berusaha untuk membantu sasaran komuniti terbebas daripada perangkap kemiskinan kebendaan. Walau bagaimanapun, didapati rata-ratanya skop visi/misi/matlamat perusahaan sosial yang dikaji adalah kurang 'berjiwa besar' untuk 'menyamakan status sosial komuniti rentan', sebaliknya tumpu pada meningkatkan kemahiran kehidupan harian mereka justeru 'berhipotesis' diharapkan dapat memberi peluang pekerjaan, menjana serta menambah pendapatan secara berterusan.

Realitinya, status komuniti terdedah tersebut bukan semudah bersiul untuk ditingkatkan melalui usaha tunggal atau dua aktiviti/program perusahaan sosial. Malah dengan berbekalkan keupayaan mencari sumber kewangan, status ekonomi mereka akan menjadi semakin stabil, dan lambat laun kualiti hidup mereka akan bertambah baik. Justeru, fenomena 'ketidaksamaan sosial' akan meresap dan 'kesamaan sosial' daripada layanan dan pandangan komuniti umum akan berubah baik. Seperti yang diperkatakan oleh Rohwerder (2016), ketidaksamaan sosial dari segi jantina, kecacatan, etnik, bangsa dan kasta adalah tidak mudah untuk ditangani. Namun, kes kajian 
ini sedikit sebanyak memberi impak terhadap pertambahan pendapatan kepada golongan ibu tunggal, petani dan orang pelarian. Pengkaji mendapati usaha yang berterusan perlu diterapkan menerusi instrumen inovasi sosial yang lebih sesuai dan pelbagai.

Instrumen inovasi sosial yang dimaksudkan termasuk segala jenis perubahan positif pada peringkat konseptual, proses, produk atau organisasi dengan penggunaan sumber yang menyumbang kepada pencapaian matlamat sosial (Mair \& Marti, 2006). Contohnya, instrumen penglibatan komuniti bersama-sama pihak perusahaan sosial dan pihak berkuasa dalam proses seperti merangka agenda untuk menjayakan sesuatu program awam, ataupun mereka suatu produk baru untuk dipasarkan. Seperti dalam situasi menghadapi cabaran pandemik wabak Covid-19, mungkin peniaga sosial bertindak dengan komuniti bersama-sama mereka produk pelitup mulut yang selamat, boleh dikitar semula dan dipasarkan dengan harga yang murah. Usaha inovasi sosial sedemikian akan dapat melengkapi usaha/sumber pihak penguat kuasa dalam mempertahankan suatu masyarakat yang bebas Covid-19.

Kategori ketiga yang ditimbulkan ialah aspek penjagaan alam sekitar. Sememangnya manusia yang mencipta alam bina dan yang mengeksploitasi sumber alam sekitar demi kemaraan dan kemajuan masyarakat. Tanggungjawab sosial dan alam sekitar adalah tepat masanya untuk dipikul oleh perusahaan sosial mahupun masyarakat umum untuk 'menyelamatkan bumi' daripada terus dilanda kemusnahan seperti perubahan iklim dan bencana besar. Kes kajian yang berusaha menggunakan barang buangan seperti banting kain plastik untuk dibuat menjadi beg dan dijual ke pasaran adalah contoh yang baik dan perlu dikembangkan. Di samping itu juga, bagi mengembangkan lagi aspek sumbangan kepada alam sekitar, peniaga sosial disyorkan lebih mengamalkan aspek belas kasihan (sympathy) dan imaginasi kepada kemusnahan alam seperti hutan, kepupusan hidupan liar seperti yang disyorkan oleh British Council (2017).

\section{Kesimpulan}

Kajian awalan kualitatif ini bertujuan untuk meninjau impak perusahaan sosial terhadap pembangunan komuniti di Malaysia. Perusahaan sosial bermatlamat bukan sekadar pada aspek menyelesaikan masalah sosial seperti memfokuskan pada komuniti rentan, membasmi kemiskinan dan menyelamatkan alam. Malah daripada dapatan kajian, 'tanggungjawab sosial' yang perlu dipikul dan bermatlamat ulungkan: membendung ketidaksamaan sosial, dengan senantiasa mengaplikasikan instrumen inovasi sosial.

Daripada perbincangan, pengkaji mendapati terdapat beberapa limitasi kajian. Pengkaji mendapati aspek impak pulangan sosial dalam kebajikan rakyat demi membantu penyelesaian bagi perkhidmatan awam yang lemah adalah kurang dibincangkan. Contohnya, selain isu kesihatan, isu kebajikan lain seperti pendidikan, kebudayaan, integrasi kerja, pengecualian sosial (Pfeilstetter \& Gómez-Carrasco 2017), kerohanian, kemudahcapaian kemudahan awam, dan kesamarataan hak di sisi undang-undang juga merupakan isu masalah sosial yang berpotensi untuk kajian lanjutan. Tinjauan lanjutan sedemikian akan dapat membantu membekalkan pemahaman yang lebih mendalam terdapat potensi mahupun halangan perusahaan sosial dalam aspek pembangunan komuniti.

Tambahan lagi, pulangan ekonomi yang tidak dinafikan sebagai nadi perusahaan sosial juga tidak dibincangkan dalam skop kajian ini. Maka, disyorkan kajian lanjutan boleh menerokai dari seri pulangan keuntungan, modal, pengurusan dan perdagangan demi memastikan kelestarian perusahaan sosial. 
Sememangnya pada bilangan kes kajian, sekadar tiga perusahaan sosial dikaji dalam kajian awalan ini adalah tidak berupaya digeneralisasikan kepada seluruh landskap Malaysia. Walaupun hasil kajian ini telah cuba membayangkan gambaran asas impak perusahaan sosial (rujuk Rajah 2). Kajian lanjutan yang melibatkan lebih banyak perusahaan dengan latar belakang yang berlainan adalah disyorkan dikaji dan dinilai balik kerang hubungan impak perusahaan sosial yang terbentuk.

Umumnya, perusahaan sosial perlu sentiasa mengangkat tanggungjawab sosial sebagai impak yang utama kepada komuniti dalam membendung ketidaksamaan sosial. Sekiranya ia tidak dilakukan, maka matlamat pertubuhan perusahaan sosial akan senang 'dihanyutkan' oleh arus komersial dan keuntungan sehingga terlupa akan matlamat sosial yang diperjuangkan pada permulaan pertubuhannya.

\section{Rujukan}

Babos, P., Clarence, \& Noya, A. (2006). Reviewing OECD experience in the social enterprise sector. Trento, OECD LEED Centre for Local Development. Retrieved from http://www.oecd.org/employment/leed/38299281.pdf

Bahena-Álvarez, I. L. I. ., Cordón-Pozo, E., \& Delgado-Cruz, A. (2019). Social entrepreneurship in the conduct of responsible innovation: Analysis cluster in Mexican SMEs. Sustainability, 11, 3714. https://doi.org/10.3390/su11133714

Baldwin, A. (2009). Creativity, social benefit and job creation: The potential for social entrepreneurship in Ontario (No. 2009-WPONT-003). Toronto, Martin Prosperity Institute. Retrieved from https://www.yumpu.com/en/document/view/17866725/creativity-socialbenefit-and-job-creation-martin-prosperity-institute

Bansal, S., Garg, I., \& Sharma, G. D. (2019). Social entrepreneurship as a path for social change and driver of sustainable development: A systematic review and research agenda. Sustainability, 11, 1019. https://doi.org/10.3390/su11041091

Becchetti, L., \& Borzaga, C. (2010). Introduction. In C. Borzaga \& L. Becchetti (Eds.), The Economics of Social Responsibility: The World of Social Enterprise (1st ed., pp. 1-14). London, Routledge.

British Council. (2017). Social entrepreneurship in Education: Empowering the next generation to address society's needs. London. Retrieved from https://www.britishcouncil.org/sites/default/files/british_council_social_entrepreneurship_in_ education_web_final.pdf

Brook Lyndhurst. (2007). Replicating success: Social enterprises \& the waste sector in Londonfinal report. London, Brook Lyndhurst Limited.

Community Wealth Ventures. (2009). Social Enterprise: A portrait of the field. Washington: Community Wealth Ventures, Inc. Retrieved from https://communitywealth.org/sites/clone.community-wealth.org/files/downloads/report-cwv-sea-case.pdf

Defourny, J., \& Nyssens, M. (2008). Social enterprise in Europe: Recent trends and developments. Social Enterprise Journal, 4(3), 202-228.

Development Strategy and Policy Analysis Unit. (2017). Global context for achieving the 2030 Agenda for Sustainable Development: Sustained global economic growth. Development Issues, 2(8), 1-3. Retrieved from https://www.un.org/development/desa/dpad/wpcontent/uploads/sites/45/publication/dsp_policy_08.pdf

Downey, J. (2007). Innovation Management. London: Chartered Institute of Management 
Accountants (CIMA). Retrieved from https://www.cimaglobal.com/Documents/ ImportedDocuments/cid_tg_innovation_management_jul07.pdf.pdf

Eurofound. (2019). Cooperatives and social enterprises: Work and employment in selected countries. Luxembourg. https://doi.org/10.2806/635150

European Commission. (2014). Science for Environment Policy In-depth Report: Social Innovation and the Environment. London, European Commission.

Fereday, J., \& Muir-Cochrane, E. (2006). Demonstrating rigor using thematic analysis: A hybrid approach of inductive and deductive coding and theme development. International Journal of Qualitative Methods, 5(1), 80-92. https://doi.org/10.1177/160940690600500107

Fotheringham, S., \& Saunders, C. (2014). Social enterprise as poverty reducing strategy for women. Social Enterprise Journal, 10(3), 176-199. https://doi.org/10.1108/sej-06-2013-0028

Freudenberg, J., \& Halberstadt, J. (2018). How to integrate refugees into the workforce - Different opportunities for (social) entrepreneurship. Management Issues, 16(1(73)), 40-60. https://doi.org/10.7172/1644-9584.73.3

Harima, A., \& Freudenberg, J. (2020). Co-creation of social entrepreneurial opportunities with refugees. Journal of Social Entrepreneurship, 11(1), 40-64. https://doi.org/10.1080/19420676.2018.1561498

Humphries, C. (2011). Social enterprise and healthcare service delivery. London, Winston Churchill Memorial Trust.

International Labour Organization. (2011). Social Business Plan Competition. South Africa, International Labour Organization.

Iorgulescu, M.-C., \& Răvar, A. S. (2015). The contribution of social enterprises to the development of tourism: The case of Romania. Procedia Economics and Finance, 32(15), 672-679. https://doi.org/10.1016/s2212-5671(15)01448-3

Kooy, J. Van. (2016). Refugee women as entrepreneurs in Australia. Forced Migration Review, 53(October), 71-73.

Lateh, M., Hussain, M. D., \& Abdullah, M. S. Bin. (2018). Social entrepreneurship development and poverty alleviation - A literature review. MAYFEB Journal of Business and Management, $2,1-11$.

Littlewood, D., \& Holt, D. (2018). How social enterprises can contribute to the sustainable development goals (SDGs) - A conceptual framework. Contemporary Issues in Entrepreneurship Research, 8(611259), 33-46. https://doi.org/10.1108/S2040724620180000008007

Madan, P. (2014). Innovative social enterprise models for rural healthcare delivery. In IDFC Foundation (Ed.), India Infrastructure Report 2013/14: The Road to Universal Health Coverage (pp. 80-100). Hyderabad, Orient BlackSwan.

Maguirre, M. V., Ruelas, G.C., \& Torre, C. G. D. La. (2016). Women empowerment through social innovation in indigenous social enterprises. Mackenzie Management Review, 17(6), 164-190.

Mair, J., \& Marti, I. (2006). Social Entrepreneurship research: A source of explanation, prediction, and delight. Journal of World Business, 41(2), 36-44. https://doi.org/10.1016/j.jwb.2005.09.002

Makararavy, T., \& Anurit, P. (2009). Impacts of training and development on social enterprises in Cambodia. NIDA Development Journal, 49(2), 23-49. https://doi.org/10.14456/ndj.2009.19

Martin, L., \& Osberg, S. (2007). Social Entrepreneurship: The case for definition. Stanford Social Innovation Review, 5(2), 30-39.

Medel-anonuevo, C. (1997). Women, education and empowerment: Pathways towards autonomy. 
Hamburg, UNESCO Institute for Education. Retrieved from https://unesdoc.unesco.org/ark:/48223/pf0000100662

Mohapatra, S., Khadanga, G. S., \& Majhi, S. (2018). Social entrepreneurship for agricultural development in India. The Pharma Innovation Journal, 7(4), 204-205.

Mollaogullari, B. F., \& Temel, R. (2017). Social entrepreneurship in Turkey: Social solution for refugee problem. International Journal of Contemporary Economics and Administrative Sciences, 7(3-4), 139-157. Retrieved from http://www.ijceas.com/index.php/ijceas/ article/view/178

Mthembu, A., \& Barnard, B. (2019). Social entrepreneurship: Objectives, innovation, implementation and impact on entrepreneurship. Expert Journal of Business and Management, $7(1), 147-177$.

Nasir, N. R. B., \& Subari, M. D. (2017). A review of social innovation initiatives in Malaysia. Journal of Science, Technology and Innovation Policy, 3(1), 10-17.

OECD. (2007). The social enterprise sector: A conceptual framework. Retrieved October 10, 2019, from http://www.oecd.org/employment/leed/37753595.pdf

OECD. (2015). Keeping the multiple dimensions of poverty at the heart of development (No. Element 1, Paper 1). Paris, Organisation for Economic Co-operation and Development. Retrieved from https://www.oecd.org/dac/POST-2015 multidimensional poverty.pdf

Parvin, G. A., Ahsan, S. M. R., \& Chowdhury, M. R. (2004). Women empowerment performance of income generating activities supported by rural women employment creation project (RWECP): A case study in Dumuria Thana, Bangladesh. Journal of Geo-Environment, 4, 4762. Retrieved from http://dept.ru.ac.bd/geography/Article_5.PDF

Pfeilstetter, R., \& Gómez-Carrasco, I. (2017). Social enterprises in Spain: Country report. Uruguay: Institute of Communication and Development. Retrieved from http://www.lasociedadcivil.org/wp-content/uploads/2017/12/Pfeilstetter_GomezCarrasco.pdf

Richardson, M., \& Sappal, B. (2017). Activitist to entrepreneur: The role of social enterprise in supporting women's empowerment in the US. London, British Council. Retrieved from https://www.britishcouncil.org/sites/default/files/social_enterprise_and_womens_empowerme nt_in_the_us_british_council_final.pdf

Rohwerder, B. (2016). Poverty and inequality: Topic guide. Birmingham, UK, GSDRC, University of Birmingham. Retrieved from https://www.shareweb.ch/site/PovertyWellbeing/resources/Documents/Poverty and Inequality Topic Guide 2016_GSDRC.pdf

Sarmila Binti Md Sum. (2012). Pembangunan komuniti melalui inisiatif tanggungjawab sosial korporat (CSR): Kajian pengalaman peserta projek perladangan cili kontrak di kawasan Bukit Awang, Pasir Puteh, Kelantan. Tesis PhD, Universiti Kebangsaan Malaysia.

Saunders, B., Sim, J., Kingstone, T., Baker, S., Waterfield, J., Bartlam, B., ... Jinks, C. (2018). Saturation in qualitative research: exploring its conceptualization and operationalization. Quality \& Quantity, 52(4), 1893-1907. https://doi.org/10.1007/s11135-017-0574-8

Sheheryar, S., Kazmi, A., \& Hashim, M. (2016). Social Entrepreneurship and its impact on economy: In perspective of Pakistan. International Journal of Academic Research in Accounting, Finance and Management Sciences, 6(4), 161-166. https://doi.org/10.6007/IJARAFMS/v6-i4/2334

Stumbitz, B., Vickers, I., Lyon, F., Butler, J., Gregory, D., \& Mansfield, C. (2018). The role of community businesses in providing health and wellbeing services: Challenges, opportunities and support needs. London, Middlesex University. https://doi.org/10.13140/RG.2.2.16459. 03369 
Vveinhardt, J. \& Kuklyte, J. (2016). Development improvement programme of social business models in Lithuania. Forum Scientiae Oeconomia, 4(4), 149-170.

Zaman, A. U. (2012). Developing a social business model for zero waste management systems: A case study analysis. Journal of Environmental Protection, 3, 1458-1469. https://doi.org/10.4236/jep.2012.311163

Zhang, Y. (2016). Social enterprises in organic farming and their usage of IT. Twenty-Second Americas Conference on Information Systems, San Diego, 1-5. San Diego. 